\title{
Regional integration and foreign direct investment in east African countries
}

\author{
Manaseh Otieno ${ }^{1,}$, , Eliud Moyi ${ }^{1}$, Dickson Khainga ${ }^{1}$, Peter Biwott ${ }^{2}$ \\ ${ }^{1}$ Kenya Institute for Public Policy Research and Analysis (KIPPRA), Nairobi, Kenya \\ ${ }^{2}$ Commission for Revenue Allocation, Nairobi, Kenya
}

\section{Email address:}

motieno@kippra.or.ke (M. Otieno), emoyi@kippra.or.ke (E. Moyi), khainga@kippra.or.ke (D. Khainga), peterbiwott2009@yahoo.co.uk (P. Biwott)

\section{To cite this article:}

Manaseh Otieno, Eliud Moyi, Dickson Khainga, Peter Biwott. Regional Integration and Foreign Direct Investment in East African Countries. Journal of World Economic Research. Vol. 2, No. 4, 2013, pp. 67-74. doi: 10.11648/j.jwer.20130204.11

\begin{abstract}
This study investigates the effect of regional integration on Foreign Direct Investment in East Africa Community countries. We apply Generalised Least Squares to examine this relationship. Regional integration did not have any effect on Foreign Direct Investment flows into the region. The degree of political risk and financial stability were positive and significant. The study recommends that Kenya and the other East Africa Community countries should institute political reforms to accompany integration in order to improve the country's ratings in terms of the degree of political risk. They should also maintain a stable exchange rate regime.
\end{abstract}

Keywords: Foreign Direct Investment, East Africa Community, Regional Integration Agreement

\section{Introduction}

The East Africa Community (EAC) is a Regional Integration Agreement (RIA) comprising 5 East African countries namely; Kenya, Uganda, Tanzania, Rwanda and Burundi. The main priority of EAC is economic cooperation, which will eventually lead to political cooperation in the long term. The EAC treaty was signed on $30^{\text {th }}$ November 1999 but came into force on $7^{\text {th }}$ July 2000 after ratification by Kenya, Uganda and Tanzania. The EAC aims at widening and deepening cooperation among the partner states for their mutual benefit.

FDI is defined as an investment made to acquire lasting management interest (normally $10 \%$ of voting stock) in a business enterprise operating in a country other than that of the investor defined according to residency. There are three major forms of FDI, namely, market seeking, resource seeking and efficiency seeking FDI. Among the expected benefits from the establishment of EAC were trade creation, factor mobility, economies of scale and external economies. Economies of scale were expected to contribute to the increased inflow of FDI and to the rise in inter-territorial trade. FDI is important to East African economies because it brings capital resources, provides new technology and enhances existing technologies. Statistics show that there has been an increase in the inflows of FDI into the region.
When the treaty came into force in 2000 , the region received a total of US\$574 million worth of FDI. With the signing of the customs union in 2005, the amount increased significantly to US\$895 million. By 2009, investments had reached US\$1585 million. The region received an average of US\$1242.65 million worth of FDI between 1990 and 2009, the minimum being US\$90 million while the maximum received was US\$4030 million. However, the region experienced a decline in FDI inflows in 2009 after having had a boom in FDI inflows in previous years (UNCTAD, 2010).

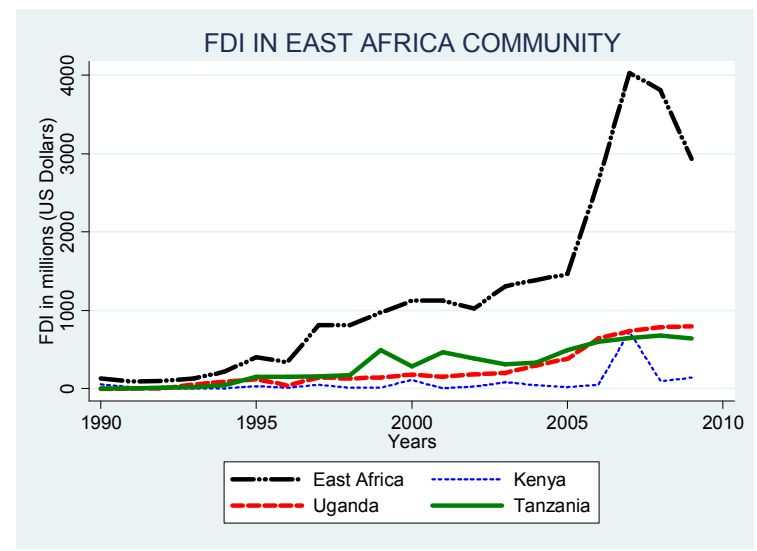

Figure 1: FDI in East African Community 1990-2009 
The impact of FDI in EAC can never be underestimated (Mwega and Ngugi, 2007). UNCTAD (2007) found that FDI was important to the EAC economy because it brought investable financial resources, provided new technology and enhanced the efficiency of existing technologies. Furthermore, FDI facilitated exports to markets therefore strengthening the export capabilities of the domestic economy. It also helped in enhancing skills and management techniques and provided better technologies and modern environment management systems. The increase in rate of technological progress takes place through contagion effect from more advanced technology and management practices used by foreign firms.

Empirical studies like Baltagi et al (2005), Aggarwal (2008) and Blomstrom and Kokko (1997) indicate that regional integration had a positive impact on FDI flow among members in a number of regional agreements. However, studies in individual EAC countries such Mwega and Ngugi (2005), Ngugi and Nyang'oro (2005), Kinuthia (2010), Day (2010), Obwona (2002) and Semwanga (2011) have focused on identifying the determinants of FDI. Others such as Obwona (2002), Semwanga (2011), Achandi (2011), Ngowi (2001) have identified the effects of FDI. Little research effort has been directed at understanding the relationship between regional integration and FDI. Therefore, this study seeks to empirically establish the relationship between regional integration and FDI in EAC countries.

\section{Theory of Regional Integration}

The theory of regional integration originates from standard trade theories which support free trade over any other trade regime (Ng'eno et al, 2001). The Ricardian model and Heckscher-Ohlin model provide the framework for pure theory of international trade. Both models advocate for free trade but differ on what drives nations to trade with each other. The Ricardian model gives technology prominence in explaining international trade patterns. The theory holds that a difference in comparative costs of production, as reflected in production techniques, is the necessary condition for the existence of international trade. According to this theory, technological differences between countries determine international division of labour, consumption and trade patterns. It concludes that trade is beneficial to all participating countries.

Heckscher Ohlin theory predicts that nations would specialise in industries most able to utilise their mix of national resources efficiently. This takes place indirectly when countries export those commodities that use intensively the factors in relative abundance. Hence, free trade in commodities could serve to equalise factor prices between countries with the same technology, even though the production inputs do not have an international market. This concept applies to the operations of multi national firms. Foreign direct investment involves international capital flows where a firm in one country creates or expands a subsidiary in another. The distinctive feature of FDI is that not only does it involve transfer of resources, but also acquisition of control. The subsidiary therefore forms part of the organisational structure apart from having financial obligation to the parent company (Krugman and Obstfield, 2009). This study is based on the Heckscher Ohlin theory as it best explains the movement of multinational firms mostly from developed to developing countries.

The Heckscher Ohlin theory explains the movement of production factors for example capital, from capital abundant to capital scarce countries, and the movement of firms from labour scarce, to labour abundant countries. Most of the multinationals come to the EAC to provide the much needed capital while taking advantage of the abundance in labour. This principle similarly works within the regional integration agreements. As an RIA advances to different stages, the more it opens up the region to trade and free movement of production factors such as labour and capital. The lowest level of integration is the formation of a preferential trading arrangement (PTA). Under the PTA, member countries agree to lower barriers to trade within the group than to trade with non-member countries. Each country determines its own policies but the trade policy of each includes preferential treatment of group members.

The PTA then moves to the free trade area (FTA) where barriers to intra group trade are eliminated while each country is allowed to retain its own nationally determined barriers to trade with non members. From the free trade area, then the region moves to a customs union, where the partners remove all barriers to intra group trade as was the case in the EAC in 2005. The members, however, maintain a common external tariff on trade with non members. The subsequent stage is the common market where the EAC currently is at. Under this arrangement, free trade is extended among members to factors of production (labour migration and capital flows) as well as to goods and services. The member countries are also expected to maintain fixed exchange rates among their national currencies. This however has not been implemented within the EAC. The most extensive form of integration is the economic union. This involves implementation of common group-determined economic policies as well as a common currency or money. Integration has the effect of reducing or eliminating protection among member countries allows them to specialize in trade according to comparative advantage and enables them to exploit potential economies of scale.

The removal of tariff or non tariff barriers among RIA partners has the effect of motivating foreign firms to produce from their home countries and sell to the host countries. This is as a result of cost reduction resulting from removal of barriers put by countries to protect their markets. The tariff jumping FDI (FDI that primarily exists to avoid the extra cost involved in exporting goods to the host countries) would then shift to their home countries because producing from there would be more attractive than relocating to the host countries. This has the effect of reducing tariff jumping FDI. On the other hand, the removal of barriers would lead 
to an increase in FDI especially for vertically integrated FDI, where one affiliate company provides inputs for the other, specialised according to their location factors. Location of production is often determined by resources. These resources could be natural or human resources. The natural resources could be minerals like copper, aluminium, oil etc, while human resources could apply to skills that are necessary in the production of goods or provision of services The trade liberalisation element of RIAs is therefore generally expected to increase the flow of FDI to the region (Yarbrough and Yarbrough, 2007).

\section{Regional Integration and FDI}

Empirical studies have begun to address the links between RIAs and FDI. Implementation of some regional agreements like European Union (EU), and North American Free Trade Agreement (NAFTA) resulted in significant increase in bilateral trade volumes among member countries. FDI also increased much faster than trade even within OECD and among the members of the mentioned RTAs (Baltagi et al, 2005).

Market size has been found to have a positive impact on FDI received by countries participating in RTAs. By increasing the size of the potential market, it could increase the quantity of investment made by both domestic and outside investors. This, alongside the size of the domestic population matters because of its effect on availability of labour supply. Most FDI were also found to migrate to countries with high per capita GDP alongside the large market size (Worth, 2008 and Fernandez, 1997).

Aggarwal (2008) examined the prospects and problems of serious fiscal consolidation within the integrating countries in South Asia. The study found that regional integration had the potential to promote intra and extra regional FDI flows and economic development in individual countries of the region. Structural weaknesses, institutional bottlenecks, political movements, narrow nationalism and mutual mistrust explained the failure of the region to exploit possibilities.

Jaummotte (2004) investigated whether the market size of an RIA was a determinant of FDI received by countries participating in the RIA. This was done by regressing the FDI received by a country against its market size as well as other determinants of FDI identified in the study. The study covered 71 developing countries involved in RIAs. This study found that; RIA market size had a positive impact on FDI received by member countries, the size of domestic population mattered because of effects on availability of labour supply and not all countries benefited equally from the RIA.

Basu and Srinivasan (2002) found that a high level of economic development reflected by the availability of quality infrastructure both human and physical was beneficial to investors in Sub-Saharan Africa. In Kenya, Mwega and Ngugi (2007), and in Pakistan, Khan and Kim (1999) found that infrastructure was a major determinant of
FDI for host countries.

Chen et al (2010) examined the investment diversion effect of an RIA, with the different productivity and income between countries based on a three-country footloose capital model. He found that the formation of an RTA induced strong investment diversion effect. More FDI was found to flow into the RTA but also possible FDI flew out of the RTA within some ranges of productivity difference between members and non members. When trade got freer, the difference between member and non member became larger, the amount of FDI among RTA became greater. Freund and Ornelas (2010) held that trade diversion could make a trade agreement harmful for both members and non members alike.

Blomstrom and Kokko (1997) dealt with the investment effects of RTAs and how such arrangements affected inward and outward flow of FDI. Their findings were that the response to RTAs depended on the environmental change brought about by the agreement and locational advantages of the participating country. Further, the most positive impact on FDI occurred when RIA agreements coincided with liberalisation and macroeconomic stabilisation in member countries.

Ayanwale (2007) investigated the empirical relationship between non extractive FDI and economic growth in Nigeria. The study went further and examined the determinants of FDI into the Nigerian economy. An augmented growth model was used to estimate via Ordinary Least Squares and Two Stage Least Squares to ascertain the relationship between FDI, its components and economic growth. Results suggested that determinants of FDI in Nigeria were market size, infrastructure development and stable macroeconomic policy. Openness to trade and available human capital were not FDI inducing. Generally, FDI did not have a significant effect on growth but components of FDI had a significant impact. FDI in the communications sector had the potential to grow the economy while manufacturing FDI negatively the economy and reflected poor business environment in the country. The available human capital was low and there was need to develop it through education and training to raise its potential to contribute to economic growth.

Obwona (2002) and Semwanga (2011) in two similar studies investigated the Ugandan experience with FDI, with the aim of establishing the FDI-growth nexus. To attract FDI, macroeconomic and political stability and policy consistency were more important than incentive schemes such as tax holidays and exemptions. Institutional and infrastructure bottlenecks were found to act as deterrents to FDI. Results from both studies confirmed that FDI had an impact on economic growth in Uganda. Achandi (2011) found that FDI inflows increased exports in Uganda and recommended that the Ugandan government maintain its policy of attracting FDI and undertake policy interventions that boost the linkage between FDI and exports to realise the optimal benefits from the inflows of FDI.

Ngowi (2001) evaluated the impact of FDI on economic development in Tanzania and concluded that although FDI 
was still at infancy stage in Tanzania, it had played and still had the potential to play a positive role in the development of the country. Day (2010) conducted a study aimed at exploring the impact of the global financial crisis on FDI inflows to Mozambique and Tanzania, countries that shared similar economic qualities yet exhibited different abilities to attract FDI during the financial crisis. The study revealed that adherence to the key indicators that serve as determinants of FDI could allow a country to realise growth in FDI inflow despite an economic climate that predicted otherwise. Government policy rather than uncontrollable resources like natural resource endowment was found to be a successful driver in attracting FDI.

In Kenya, studies conducted on FDI revealed that institutional factors were important in attracting FDI into the country. These are law and order, corruption, political stability, internal conflict and civil liberties among others. The other major drivers of FDI were the macroeconomic environment, a conducive business environment, market size and trade agreements (Mwega and Ngugi, 2005; Ngugi and Nyangoro, 2005 and Kinuthia, 2010). The most serious impediments to attracting FDI were identified as political instability and corruption.

This literature survey demonstrates that a lot has been done in identifying the determinants of FDI in Africa, but little or nothing has been done to establish how regional integration has affected FDI inflow in Africa leave alone the EAC. This study will consequently fill the literature gap that is apparent in the existing studies.

\section{Methodology}

The model used in this study is a variant of the model used by Jaummotte (2004), which was modified to include variables that had been identified by Basu and Sirinivasan (2002) and Mwega and Ngugi (2007). This model takes into account factors such as market size, quality of local labour, political risk, level of economic development and openness of the economy.

Host market size plays an important role in attracting FDI. Jaummotte (2004), Worth (2008) and Fernandez (1997) found that market size played an important role in attracting FDI especially when the host country market allowed the exploitation of economies of scale for import substituting investment. This was proxied by Per Capita GDP or $Y_{i, t}$. This variable is expected to have a positive impact on FDI.

Secondly, the cost and quality of labour denoted (LBR) has been identified as another significant factor in location considerations. This particularly applies to export oriented investment. Investors would also like to operate in countries that allow employment of expatriate staff (Basu and Sirinivasan, 2002). This was proxied by the Human Development Index (HDI). HDI is the geometric mean of the three dimension indices;

$$
\left(I_{\text {Life }}^{\frac{1}{3}} \cdot I_{\text {Education }}^{\frac{1}{3}} \cdot I_{\text {Income }}^{\frac{1}{3}}\right)
$$

measuring achievement in each dimension. This expression represents imperfect substitutability across all HDI dimensions. The life expectancy index takes into account life expectancy at birth, education index takes into account the mean and expected years of schooling and finally, the gross national income gives the index for gross national income that indicates a decent standard of living (UNDP, 2010). It is expected to be positive, especially if the type of FDI present in the country is efficiency seeking. HDI is a good measure for cost and quality of labour because the education component determines both the cost and quality of labour. The availability of low skilled (in terms of years of schooling) labour implies lower production costs and hence validates relocation of production processes to foreign countries. However in instances where there is intensive use of technology in production, firms may demand highly educated workers because they're more interested in the quality of output. The education component measured by the number of years of schooling adequately captures these two elements. The life expectancy component captures the quality of life, in terms of health and the number of years one is expected to live. Healthy workers as opposed to sickly ones, are more productive and are likely to deliver more output.

Financial stability denoted (STABFIN) was proxied by the real effective exchange rate. A depreciation of the real exchange rate can be expected to encourage FDI inflows and discourage outflows by enhancing the competitiveness of the economy. This variable is expected to be positive since a strong exchange rate reduces the amount of investment in the economy (Jaumotte, 2004). The real exchange rate was calculated using the formula presented below:

$$
r=e \frac{p^{*}}{p}
$$

Where $r$ : Real effective exchange rate

$e$ : Nominal exchange rate

$p^{*}$ : Foreign prices

$p$ : Domestic prices

Fourth, the infrastructure index denoted (INFRST) was used as a proxy for the quality of infrastructure. This index was constructed using the Principal Component Analysis method. Well developed infrastructure has been found to be an incentive to locate new FDI close to existing FDI. Infrastructure is therefore an agglomeration related variable that qualifies to be a determinant of FDI, for this reason is expected to have a positive sign (Jaumotte, 2004; Mwega and Ngugi, 2007 and Basu and Sirinivasan, 2002). The methodology for construction of the infrastructure index is given below:

The Principal Component Analysis gives a linear combination of optimal weighted observed variables;

$$
C_{1}=b_{11}\left(x_{1}\right)+b_{12}\left(x_{2}\right)+\ldots b_{1 p}\left(x_{p}\right)
$$

Where;

$$
C_{1}=\text { score on principal component } 1
$$


$b_{1 p}=$ regression coef ficient or weight $x_{p}=$ The subject's score on the observed variable $p$

The components used in the construction of this index were;

1. Air transport freight in millions per ton.

2. The number of air transport passengers.

3. Rail total route in $\mathrm{km}$.

4. Railways goods transported.

5. Mobile phones per 1000 people.

6. Fixed telephone lines per 1000 people.

Fifth, the degree of a country's openness $(O P E N)$ affects FDI in multiple ways. Lower import barriers discourage tariff jumping FDI but may stimulate vertical FDI by facilitating imports of inputs and machinery. Lower export barriers facilitate re-export of processed goods and thereby increasing (non tariff jumping) horizontal FDI by expanding the market size leading to an improved business climate and higher expectations of better long term economic growth. This was measured by the trade to GDP ratio. This variable is expected to have a negative sign because the more a country opens up, the more it is accessible from outside hence no need for a foreign firm to relocate there.

Political stability (PIN) encompasses perceptions of civil unrest, instability of government and violation of civil liberties. Political instability may constitute a large part of the total risk investors face when investing in emerging markets. Political instability is found to be significantly negative in developing countries. Investors are also concerned about the quality of institutions. This relates to the safeguard for their property rights and the bureaucratic red tape of undertaking investment. Potential investors consider the rule of law, strong and clearly defined property rights the extent of corruption, the regulatory framework and local bureaucracy in making their decisions (Blomstrom and Kokko, 2003). This variable is expected to be positive because an improvement in the country's ranking in the degree of political risk (the lowest rank is high risk where a country has the lowest percentage points whereas low risk refers to a country that has scored high points in terms of perception of political stability), would lead to greater inflows of FDI.

Additional variables were used to measure the locational advantage of the EAC countries. REGY denotes market size extended to include RTA market size for countries belonging to an RTA. The regional market size is calculated as the sum of the domestic market size and the market size of all the countries within the EAC. The prefix GAP denotes the ratio between the domestic value of the variable and the average value for all the countries in the EAC (including Kenya). The variable $D_{1 \mathrm{t}}$ is a dummy variable that was used to distinguish between periods before and after EAC integration where;

$D_{1 \mathrm{t}}=1$ if it was during the period after integration (2000-2009)

1990-1999)
The coefficient attached to the dummy variable indicates whether integration had an effect on FDI if it is found to be statistically significant. This variable is expected to be positive.

Lagged values were taken to account for the suspected presence of endogeneity among the independent variables.

$$
\begin{aligned}
& L N F D I_{i, t}=\varphi_{1} L N Y_{i, t-1}+\varphi_{2} L B R_{i, t-1}+ \\
& \varphi_{3} \text { LNSTABFIN }_{i, t-1}+\varphi_{4} \text { INFRST }_{i, t-1}+ \\
& \varphi_{5}{ }_{\text {LNOPEN }}, t-1+\varphi_{6} \operatorname{PIN}_{i, t-1}+ \\
& \varphi_{7} R E G Y_{i, t-1}+\varphi_{8} G A P L B R_{i, t-1}+ \\
& \varphi_{9} \text { GAPSTABFIN }_{i, t-1}+\varphi_{10} \text { GAPINFRST }_{i, t-1}+ \\
& \varphi_{11} \text { GAPOPEN }_{i^{\prime} t-1}+\varphi_{12} \text { GAPPIN }_{i, t-1}+ \\
& D_{1, t}+\varepsilon_{i}
\end{aligned}
$$

Equation (1) was regressed on panel data for the three countries; Kenya, Uganda and Tanzania (leaving out Rwanda and Burundi since they are late entrants into EAC and therefore had insufficient data points) over the period 1990-2009. The study used data from World Development Indicators, UNCTAD World investment reports and the EAC Secretariat.

\section{Results}

Model 1 was first tested for specification errors using the Ramsey Regression Specification Error test. Powers of the fitted values of $\log$ FDI were used to check whether the model had any omitted variables. Given that the F statistic was found to be insignificant, it was concluded that the model had no omitted variables. Further, the Breusch-Pagan / Cook-Weisberg test for heteroskedasticity was conducted to check whether the variance in the disturbance term was constant. The null hypothesis of constant variance was not accepted given the results. Given the presence of panel heteroskedasticity, the Generalised Least Squares (GLS) was used.

Table 1 gives the descriptive statistics for the variables. FDI had a mean value of US\$210.68 million, a minimum of US\$ -5.91 million which was attributed to the net outflow of FDI from Uganda in 1990 as it was stabilising from a period of internal conflict and a maximum of US\$ 798.77 million which was similarly received by Uganda in 2009.

Political instability represented by the political risk index had a mean of 57.8, a minimum of 37 scored by Uganda in 1991 five years after it emerged from a civil war and maximum of 68.08 percentage points scored by Tanzania in 1995. GDP per capita had a mean of 336.95 , a minimum of 181 scored by Uganda in 1990 and a maximum of 457 scored by Kenya in the year 2007 when the country experienced its highest economic growth. The real exchange rate had a mean of 699.20 a minimum of 5.4925 and a maximum of 2657.455. The infrastructure index which measures the quality of infrastructure had a mean of 0.0000003 a minimum of -1.14 which indicated deterioration of infrastructure in Tanzania and a maximum of 2.62 points attributed to the Kenya government's heavy 
investment aimed at improving the country's quality of infrastructure. The degree of openness had a mean of 36.91 percent, a minimum of 20 percent and a maximum of 66 percent. The quality of labour represented by the human development index had a mean of 0.38 , minimum of 0.31 and a maximum of 0.42 . GAPGDP had a mean of 1 , minimum of -1 and a maximum of 3 . GAPREER had a mean of 1 , minimum of 0 and maximum of 2.8. GAPINFRST had a mean of 1 , minimum of 0.26 and maximum of 2.01 . GAPOPEN had a mean of 1 , minimum of 0 and maximum of 2.1. GAPHDI had a mean of 0.33 , minimum of 0.73 and maximum of 1.19 .

Table 2 reports OLS and GLS estimates of the model. Results revealed positive and significant values for financial stability (1.098), proxied by the real exchange rate and the degree of political risk (0.113), as measured by the ICRG political risk ratings. The GAP in degree of political risk was found to be negative and significant with a coefficient of -5.934. The dummy representing regional integration was insignificant like the rest of the other variables though positive.

The coefficient for financial stability was positive indicating that an increase in the real effective exchange rate would lead to the increase in FDI flow within the EAC. These results suggest that holding other factors constant, a 1 percentage increase in the real effective exchange rate would result in a 1.1 percentage increase in FDI flow in the EAC. This finding was similar to results obtained by Jaumotte (2004) whose study revealed that a strong exchange rate reduced the amount of investment in the economy. Depreciation of the real exchange rate (as a proxy for financial stability) plays a big role in attracting FDI because it makes investing in the EAC countries cheaper for foreign investors. When a country's currency depreciates, it loses value with respect to the value of the other currencies. This country becomes attractive as an investment destination because both wage and production costs become cheaper compared to the other countries. This improves the overall rate of return to multinational firms considering making investments into the country. However, long run exchange rate volatility may lead to risk aversion by foreign investors as this worsens their position in terms of the expected future profits.

The degree of political risk was important in determining the magnitude of FDI inflows into the EAC region. This variable was found to be positive and significant. The findings suggest that a 1 unit improvement in rankings of degree of political risk would lead to 11.9 percentage increase in the net FDI inflow into the region. It should be noted that in the ICRG ratings of political risk, a country is considered high risk if it accumulates the least points in terms of political risk ratings ranging 1 . The closer a country is to attaining the maximum 100 percentage points, the more it is considered as low risk. Thus, political risk affects FDI flows. This is because investment as a forward looking activity is based on the anticipation of future returns. In the EAC, foreign investments are positively related to political stability. Foreigners are less willing to risk in a politically unstable environment because it eventually reduces the rate of return on investment. It also lowers the economic value of the firm's assets after a period of conflict, regardless of whether the conflict was internal or external.

The GAP in degree of political risk was significant but negative. Therefore, a decrease in the country's political risk rating below the region's average would lead to a 99.7 percent (this was found after getting the exponential value of -5.934) decline in net FDI inflow. This shows that countries, whose political risk ratings deteriorate, would lose FDI to their partner states since the Multinational firms will relocate to countries where there is political certainty and guaranteed security for their investments.

Table 1. Descriptive Statistics

\begin{tabular}{llllll}
\hline Variable | & Obs & Mean & Std. Dev. & Min & Max \\
\hline Foreign direct & 60 & 210.6816 & 243.0577 & -5.91 & 798.7714 \\
investment | & 60 & 336.95 & 81.85362 & 181 & 457 \\
Market size | & 57 & .3799392 & .0300918 & .312 & .424 \\
Quality of labour | & 60 & 699.2064 & 693.0925 & 5.4925 & 2657.455 \\
Real exchange rate| & 60 & .0000003 & .9999995 & -1.14007 & 2.62512 \\
infrastructure | & 60 & 36.91228 & 11.79479 & 20 & 66 \\
Degree of openness | & 57 & 57.79583 & 6.822101 & 37 & 68.08334 \\
Political risk| & 60 & 1 & .0973191 & .7306035 & 1.189078 \\
Gap in political risk | & 60 & 1 & .2281777 & .5801282 & 1.442308 \\
Gap in market size | & 60 & .3333333 & .0951301 & 0 & .5468608 \\
Gap quality of labor | & 60 & 1 & .851306 & .0339003 & 2.703019 \\
Gap in real exchange & 60 & 1.000168 & 218.6053 & -1293.7 & 1036.26 \\
rate | & 1 & .4126756 & 0 & 2.096385 \\
Gap in infrastructure | & 60 & 60 & & & \\
Gap in openness | & & & & \\
\hline
\end{tabular}


Table 2. OLS and GLS Regression Results

\begin{tabular}{|c|c|c|}
\hline & Panel OLS & Panel GLS \\
\hline VARIABLES & FDI & LogFDI \\
\hline Log Regional market size & $3.039 \quad(3.699)$ & $3.039(3.244)$ \\
\hline Log Financial stability & $1.098 *(0.616)$ & $1.098 * *(0.540)$ \\
\hline Degree of openness & $0.576(1.506)$ & $0.576(1.321)$ \\
\hline Degree of Political risk & $0.113(0.0743)$ & $0.113 *(0.0652)$ \\
\hline Quality and cost of labour & $3.793(7.690)$ & $3.793(6.745)$ \\
\hline GAP in quality of labour & $4.490(3.403)$ & $4.490(2.985)$ \\
\hline Regional integration dummy & $0.221(0.766)$ & $0.221(0.672)$ \\
\hline GAP in financial Stability & $0.0118(1.370)$ & $0.0118(1.201)$ \\
\hline GAP in degree of openness & $0.256(0.798)$ & $0.256(0.700)$ \\
\hline GAP in degree of political risk & $-5.934 *(3.438)$ & $-5.934 * *(3.015)$ \\
\hline Constant & $-27.15(19.00)$ & $-27.15(16.66)$ \\
\hline Observations & 52 & 52 \\
\hline R-squared & 0.698 & \\
\hline Number of id & 3 & \\
\hline \multicolumn{3}{|l|}{ Diagnostic tests } \\
\hline Ramsey Reset Test (p-value) & 0.1687 & \\
\hline Ho: Model has no omitted variables & & 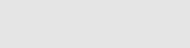 \\
\hline Breusch Pagan/Cook Weisberg test for heteroskedasticity (p-value) & 00000 & 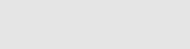 \\
\hline Ho: Constant variance & 0.0000 & 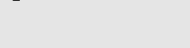 \\
\hline Wald test & & 77.10 \\
\hline $\mathrm{p}$-value & & 0.0000 \\
\hline
\end{tabular}

+ Standard errors in parentheses $* * * \mathrm{p}<0.01,{ }^{* *} \mathrm{p}<0.05,{ }^{*} \mathrm{p}<0.1$

\section{Conclusion and Recommendations}

Regional integration in EAC countries did not have any effect on FDI inflows into the region according to the findings from this study. However, financial stability and the degree of political risk have played a significant role in determining the magnitude of FDI flows into the East African region. Given these findings, we recommend that the countries in the EAC should prioritize political stability by enhancing the rule of law, promoting internal security, reducing corruption, promoting transparency and accountability, and improving the quality of countries' bureaucracy. These countries should also maintain financial stability so that investors have confidence in their expected future profits. As much as countries experiencing real exchange rate depreciation have the advantage of attracting foreign investment, EAC countries should protect themselves against exchange rate volatility because this will discourage foreign investors. Exchange rate stability will attract risk averse investors who seek certainty in the expected future profits.

\section{References}

[1] Achandi, E.L. (2011). Effect of FDI on Export Performance in Uganda. Makerere University, Kampala Uganda.

[2] Aggarwal, A. (2008). Regional Economic Integration and FDI in South Asia: Prospects and Problems. Indian Council for Research on International Economic Relations.

[3] Ayanwale, A.B. (2007). FDI and Economic Growth: Evidence from Nigeria. Proceeding of the AERC Research paper 165 AERC, Nairobi.

[4] Baltagi, H.B., Peter, E. and Pfattermayr, M. (2005). Estimating Regional Trade Agreement Effects on FDI in an Interdependent World. Syracuse University Center for Policy Research. Maxwell School of Citizenship and Public Affairs.

[5] Basu, A. and Srinivasan, K. (2002). Foreign Direct Investment in Africa - Some Case Studies. IMF Working Paper, No 02/61, Washington DC.

[6] Blomstrom, M. and Kokko, A. (1997). Regional Integration and Foreign Direct Investment. Working Paper series in Economics and Finance No. 172 
[7] Blomstrom, M. and Kokko, A. (2003). The Economics of Foreign Direct Investment Incentives. Working Paper 9489. National Bureau of Economic Research NBER, USA

[8] Chen, L., Yu, C. and Huang, J. (2010). How The Regional Trade Agreement affects FDI. Based on Three-Country Footloose Capital model, School of International Business, Southwest University of Finance and Economics (SWUFE), Chengdu, China.

[9] Day, J. (2010). The Relationship between Financial Crisis and Foreign Direct Investment. A Study of the 2007-2009 financial crisis and its impact onj FDI inflows to Mozambique and Tanzania. Submitted to Central European University. Dept of Public Policy. Budapest. Hungary.

[10] Fernandez, R. (1997). Returns to Regionalism. An Evaluation of Non Traditional Gains From Regional Trade Agreements. The World Bank, International Economics Department, International Trade Division.

[11] Jaumotte, F.(2004). Foreign Direct Investment and Regional Trade Agreements: The market Size effect revisited. International Monetary Fund. Working Paper. Middle East and Central Asia Department.

[12] Kinuthia, K.B. (2010). Determinants of FDI in Kenya: New Evidence. Africa Studies Centre. Leiden, the Netherlands. University of Nairobi School of Economics, Nairobi Kenya. Paper submitted for the annual African International Business and Management (AIBUMA) conference Nairobi. August 2010.

[13] Mwega, F.M. and Ngugi, R.W. (2007). Foreign Direct Investment in Sub Saharan Africa: Determinants, Origins, Targets, Impact and Potential. African Economic Research Consortium. Pp 119-143
[14] Ng'eno, N. K., H. O. Nyangito, M. M. Ikiara, E. Ronge and J. Nyamunga (2001), "Regional Integration in East Africa: The Case of Kenya". Paper Submitted to the African Centre for Economic Growth (ACEG), Nairobi, Kenya.

[15] Ngowi, P.H. (2001). Attracting New Foreign Direct Investment to Tanzania. Institute of Development Management, Mzumbe, Tanzania.

[16] Ngugi, R.W. and Nyangoro, O. (2005). Institutional Factors and Foreign Direct Investment Flows: Implications for Kenya. Private sector Development Division. Kenya Institute for Public Policy Research and Analysis. KIPPRA Discussion Paper No. 48. Nairobi.

[17] Obwona, B.M. (2002). Determinants of FDI and their impact on Economic Growth in Uganda. African Development Review. Vol. 13 Issue1, Pp 46-81.

[18] Semwanga, J.P. (2011) FDI and Economic Growth; The case of Uganda (1970- 2007). Makerere University. Kampala. Uganda.

[19] UNCTAD (2007). Africa Foreign Investor Survey 2005. Understanding the contributions of different investor categories to development implications for targeting strategies. $2^{\text {nd }}$ Edition. Vienna: UNIDO.

[20] UNCTAD (2010). Trade and Investment Report. New York: The United Nations.

[21] UNDP (2010). Human Development Report. The Real Wealth of Nations: Pathways to Human Development

[22] Worth, T. (2008). Regional Trade Agreements and Foreign Direct Investment. 